\title{
Assessment of Groundwater Quality and Hydrogeological Profiles within Odeda Local Government, Abeokuta, Southwest Nigeria
}

\section{*OLATUNDE, KA; SANNI, M; OMODAYO, A; ODEDEYI, D; EZE, J; OJO, A; AJE, D; OYEWOLE, O}

\author{
Department of Environmental Management and Toxicology, Federal University of Agriculture, Abeokuta, Nigeria \\ *Corresponding Author Email: Olatundeka@funaab.edu.ng
}

\begin{abstract}
Groundwater quality can be affected by human activities such as agriculture and improper sewage disposal facilities currently in use by some homeowners within Odeda local government, Ogun State Nigeria. Sixty groundwatersamples collected from hand-dug wellswere analysed for physicochemical and bacteriological parameters using standard procedures. Results were integrated with multivariate and hydrogeochemical analyses to assess groundwater quality and hydrogeologycal facies within the study area. The range of values for the measured parameters include: $\mathrm{pH}\left(5.91\right.$ - 7.4), EC (101- $\left.1142 \mu \mathrm{Scm}^{-1}\right)$, TDS (50 - $\left.581 \mathrm{mg} \mathrm{L}^{-1}\right), \mathrm{NO}_{3}^{-}\left(3-18 \mathrm{mg} \mathrm{L}^{-1}\right), \mathrm{Cl}^{-}\left(25-234 \mathrm{mg} \mathrm{L}^{-1}\right), \mathrm{BOD}$ $(0.1-17.9)$ and E. Coli (ND - $\left.45 \times 10 \mathrm{cfu} \mathrm{mL}^{-1}\right)$. The piper trilinear plot shows that the dominant hydrochemical facies in the study area is the $\mathrm{Ca}^{2+}-\mathrm{Cl}^{-}$type. A correlation analysis and a principal component analysis reflect dissolutions from basal rocks and contamination from biological wastes possibly arising from surrounding septic tanks or municipal waste disposal sites. There is need for a continuous monitoring of groundwater by relevant regulatory authorities to safeguard the human health and environment within the study area.
\end{abstract}

\section{DOI:https://dx.doi.org/10.4314/jasem.v25i5.5}

Copyright: Copyright $($ ) 2021Olatunde et al. This is an open access article distributed under the Creative Commons Attribution License (CCL), which permits unrestricted use, distribution, and reproduction in any medium, provided the original work is properly cited.

Dates: Received: 20March 2021; Revised: 27April 2021; Accepted: 07May 2021

Keywords: Odeda; Groundwater; Quality; Sewage; Hydro-chemical facies

Availability and access to water that is fit for purpose is a daily challenge in developing countries such as Nigeria (USAID, 2018).Out of the various water sources available, ground water remains the largest available source of fresh water. A large part of the population in rural areas rely on hand-dug wells for potable water supply especially in dry seasons when streams and other surface waters dry up (Olatunde et al., 2021). Groundwater quality is however threatened by organic and inorganic pollution arising from activities such as agriculture and waste disposal. Of major importance is the presence of organic pollution from the type of sewerage systems employed by the population (Kayode et al., 2018).Improperly built septic tanks currently in use by most homeowners within Odeda local government do not meet specification for sewage management and can serve as a medium for the spread of water borne diseases such as cholera, dysentery, schistosomiasis, lymphatic filariosis, parasitic and viral infections. The rise in population and unchecked physical development coupled with observed sanitary issues within the study location makes an assessment of groundwater quality essential. In addition, the use of modified septic tank units is a recent trend and the extent of its use and potential environmental impact has not been fully documented. Therefore, a detailed study on groundwater quality in relation to the use of these modified septic tanks units is essential within Odeda local government, Abeokuta. This will assist in determining the potential effects of this recent trend on ground water quality and the possible health risk the consuming population may be exposed to.

\section{MATERIALS AND METHODS}

Study Area: Odeda Local Government Area is a fast developing peri-urban area located on the outskirts of Abeokuta, Ogun state, Nigeria. It extends from longitude $3.3899 \mathrm{E}$ to $3.47950 \mathrm{E}$ and latitude $7.1745 \mathrm{~N}$ to $7.2300 \mathrm{~N}$. The study area is characterized by a tropical climate with two seasons: wet and dry seasons. The major communities within the study area from which groundwater were collected for this study include Osiele (OS), Camp (CA), Odo eran(OE) and Somorin (SO)(Figure 1). The study area underlain by sedimentary formations is regarded as having good potential for groundwater due to the presence of aquiferous sandy layer. Water levels in hand-dug wells sampled occur at a depth of $4.5-14 \mathrm{~m}$. Majority of residents within the study area depend on groundwater for water supply while a few around OS community depend on streams during the wet season. 


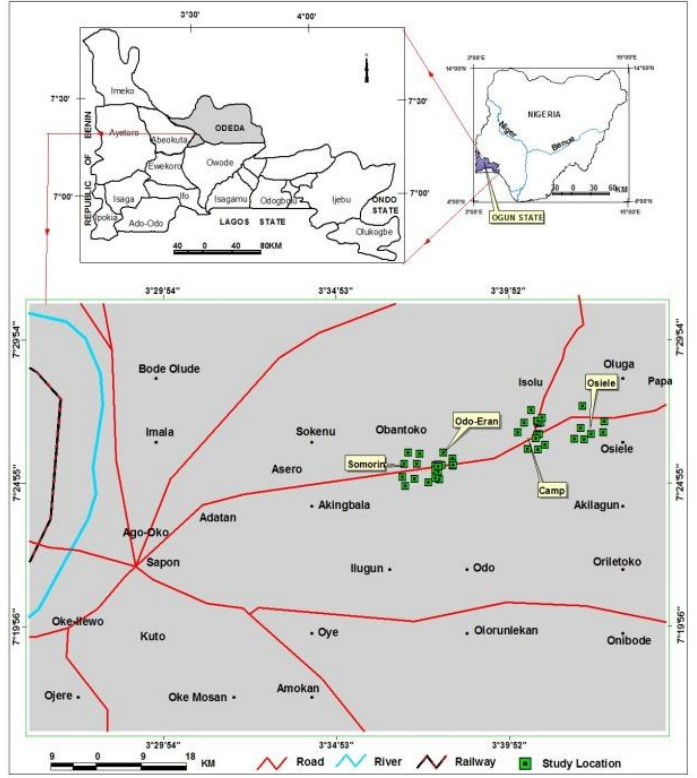

Fig1: Map of study area.

Sample Collection and Analysis: Sixty (60) water samples (fifteen from each community) were collected from hand-dug wells $\leq 15 \mathrm{~m}$ from improperly constructed or old/broken septic tank units in February, 2019. Water samples were collected in acid washed PET bottles to avoid contamination during sampling. Analytical blanks were included during laboratory analysis and all chemicals used were of analytical grade to ensure quality control. $\mathrm{pH}$, temperature, total dissolved solids (TDS) and electrical conductivity were determined during sample collection using an HI98129 electrode which had been calibrated with buffers $\mathrm{pH} 4.0$ and 9.0. Cations $\mathrm{Ca}^{2+}$, $\mathrm{Mg}^{2+}, \mathrm{Na}^{+}$and $\mathrm{K}^{+}$were determined using the PerkinElmer Pin AAcle 500 FAA spectrometer, while anions $\mathrm{SO}_{4}{ }^{2-}, \mathrm{PO}_{4}{ }^{3-}, \mathrm{NO}_{3}{ }^{-}$and $\mathrm{Fe}^{2+}$ were determined by Hach DR/2000 spectrophotometer. $\mathrm{Zn}^{2+}$ concentration in digested water samples were analyzed using a Buck 2015 AA atomic absorption spectrophotometer while total coliform counts (TCC) and Escherichia Coli were determined by using the Millipore filtration method.
Multivariate Statistical Analysis: The data obtained from laboratory investigations were subjected to descriptive statistics and multivariate analysis using SPSS 23.0 software. To evaluate the relationships between water quality parameter, a correlation analysis was used while a principal component analysis (PCA) was conducted to investigate the possible sources of contamination. The Piper trilinear diagram, a hydrogeological plot was also drawn to identify relevant dominant water types within the study area.

\section{RESULTS AND DISCUSSION}

Results of water quality parameters are presented in Table 1.Hydrogen ion concentration $(\mathrm{pH})$ values of groundwater sampled ranged from5.91 - 7.4.About $33 \%$ (20) of the total wells sampled had $\mathrm{pH}$ values less 6.5 limit for potable water (WHO, 2017; NSDWQ, 2015). Average $\mathrm{pH}$ of all groundwater samples within this study was found to be 6.61 . Waters with $\mathrm{pH}$ less than 6.5 are more likely to contain microbial contaminants that can pose negative effects on the gastrointestinal tracts when consumed, thereby, resulting in diarrhea (Elemile et al., 2019).Electrical conductivity (EC) of groundwater samples ranged between $101 \mu \mathrm{Scm}^{-1}$ to $1142 \mu \mathrm{Scm}^{-1}$ with an average of $434.15 \mathrm{~cm}^{-1}$. Only one well had EC level above the acceptable limit of $1000 \mu \mathrm{S} \mathrm{cm}$. Waters with EC greater than $700 \mu \mathrm{S} \mathrm{cm}^{-1}$ are considered unsuitable for irrigation purposes (Narany et al., 2014). The TDS values for all groundwater samples ranged between 50 $\mathrm{mgL}^{-1}$ and $581 \mathrm{mg} \mathrm{L}^{-1}$ and with an average of $216.34 \mathrm{mg}$ $\mathrm{L}^{-1}$. Two samples fell outside the WHO and NSDWQ maximum acceptable limit of $500 \mathrm{mg} \mathrm{L}^{-1}$. 16.7\% (10) of the total water samples had TDS content above $300 \mathrm{mg} \mathrm{L}^{-1}$, the ideal TDS limit for potable water (BIS, 2012). The general abundance of cations in groundwater samples is in the order $\mathrm{K}^{+}<$ $\mathrm{Na}^{2+}<\mathrm{Mg}^{2+}<\mathrm{Ca}^{2+} . \mathrm{K}^{+}$is the least abundant cation with concentrations ranging from $8 \mathrm{mg} \mathrm{L}^{-1}$ to $83 \mathrm{mg} \mathrm{L}^{-1}$ and an average of $13.08 \mathrm{mg} \mathrm{L}^{-1}$ for the study area. Sodium varied from $3 \mathrm{mg} \mathrm{L}^{-1}$ to $18 \mathrm{mg} \mathrm{L}^{-1}$. All the samples have sodium concentrations within the permissible limit of $200 \mathrm{mg} \mathrm{L}$.

Table 1:Physical parameters for groundwater samples

\begin{tabular}{|c|c|c|c|c|c|c|c|c|c|c|c|c|c|c|c|c|}
\hline & Sample & $\mathrm{pH}$ & Tem & $\mathrm{EC}$ & TDS & $\mathrm{Na}^{+}$ & $\mathrm{K}^{+}$ & $\mathrm{Ca}^{2+}$ & $\mathrm{Mg}^{2+}$ & $\mathrm{Cl}^{-}$ & $\mathrm{NO}_{3}{ }^{-}$ & $\mathrm{SO}_{4}{ }^{2-}$ & $\mathrm{PO}_{4}{ }^{3-}$ & $\mathrm{HCO}_{3}{ }^{-}$ & $\mathrm{Fe}$ & $\mathrm{Zn}$ \\
\hline & & & $\left({ }^{\circ} \mathrm{C}\right)$ & $\left(\mu \mathrm{S} \mathrm{cm}^{-1}\right)$ & \multicolumn{12}{|c|}{$\left(\mathrm{mg} \mathrm{L}^{-1}\right)$} \\
\hline \multirow{3}{*}{ OS } & Min & 5.91 & 25.80 & 101.00 & 50.00 & 10.00 & 1.20 & 40.00 & 36.00 & 26.00 & 3.82 & 11.00 & 9.00 & 12.09 & 0.01 & 0.05 \\
\hline & Max & 7.08 & 26.10 & 1142.00 & 588.00 & 80.00 & 80.00 & 268.00 & 164.00 & 157.00 & 16.20 & 83.00 & 48.00 & 47.47 & 0.43 & 0.18 \\
\hline & Mean & 6.61 & 25.98 & 493.53 & 248.67 & 27.73 & 14.68 & 138.67 & 77.73 & 67.40 & 8.30 & 33.07 & 20.78 & 24.65 & 0.13 & 0.12 \\
\hline \multirow{3}{*}{$\mathrm{CA}$} & Min & 6.19 & 25.90 & 109.00 & 54.00 & 9.00 & 1.00 & 17.80 & 39.00 & 25.00 & 3.00 & 15.00 & 10.70 & 16.04 & 0.01 & 0.04 \\
\hline & Max & 7.26 & 27.20 & 788.00 & 394.00 & 109.00 & 41.00 & 240.00 & 109.00 & 234.00 & 17.00 & 73.00 & 51.30 & 28.01 & 0.16 & 0.18 \\
\hline & Mean & 6.58 & 26.39 & 400.47 & 201.00 & 34.87 & 11.09 & 136.52 & 58.40 & 66.27 & 9.59 & 37.20 & 30.18 & 24.24 & 0.05 & 0.12 \\
\hline \multirow{2}{*}{$\mathrm{OE}$} & Min & 6.13 & 25.90 & 213.00 & 107.00 & 16.00 & 3.00 & 40.00 & 17.00 & 33.00 & 3.00 & 10.00 & 12.00 & 20.61 & 0.01 & 0.05 \\
\hline & Mean & 6.69 & 26.71 & 352.93 & 170.00 & 29.28 & 11.60 & 124.27 & 39.73 & 60.40 & 7.00 & 25.33 & 21.32 & 29.47 & 0.03 & 0.17 \\
\hline \multirow{3}{*}{ SO } & Min & 5.97 & 27.00 & 123.00 & 62.00 & 17.00 & 3.00 & 66.00 & 18.00 & 30.00 & 4.00 & 8.00 & 11.00 & 13.70 & 0.01 & 0.04 \\
\hline & Max & 7.13 & 27.60 & 813.00 & 405.00 & 109.00 & 52.00 & 248.00 & 90.00 & 122.00 & 18.00 & 81.00 & 53.00 & 52.80 & 0.15 & 0.35 \\
\hline & Mean & 6.60 & 27.25 & 489.67 & 245.80 & 59.00 & 14.93 & 143.07 & 53.40 & 64.13 & 9.34 & 33.47 & 26.93 & 28.60 & 0.05 & 0.17 \\
\hline
\end{tabular}


Calcium in water samples ranged from $17.8 \mathrm{mg} \mathrm{L}^{-1}$ to $268 \mathrm{mg} \mathrm{L}^{-}$with an average of $135.68 \mathrm{mg} \mathrm{L}^{-1}$ for the study area. $\mathrm{Mg}^{2+}$ ranged from $13 \mathrm{mg} \mathrm{L}^{-1}$ with an average of $57.32 \mathrm{mg} \mathrm{L}^{-1}$. More than half $(72 \%)$ of groundwater samples had $\mathrm{Ca}^{2+}$ greater than $75 \mathrm{mg} \mathrm{L}^{-1}$ recommended limits. Similarly, $86 \%$ of groundwater samples within this study had $\mathrm{Mg}^{2+}$ greater than $20 \mathrm{mg} \mathrm{L}^{-1}$ for drinking water.Chlorine, an indicator for sewage contamination is the most abundant of anions in water samples. $\mathrm{Cl}^{-1}$ in groundwater within this study has an average of $64.55 \mathrm{mg} \mathrm{L}^{-1}$.Nitrates in groundwater samples have an average of $8.56 \mathrm{mg} \mathrm{L}^{-1}$ and ranges from $3 \mathrm{mg} \mathrm{L}^{-1}$ to $18 \mathrm{mg} \mathrm{L}^{-1}$. $28 \%$ of groundwater samples within the study area contained nitrates above the $10 \mathrm{mg} \mathrm{L}^{-1}$ allowable limit for potable water.Phosphates in groundwater samples ranges from $9 \mathrm{mg}$ to $53 \mathrm{mg} \mathrm{L}^{-1}$ with an average of $24.74 \mathrm{mg} \mathrm{L}^{-1}$ for the study area. The presence of nitrates and phosphates in groundwater can be linked to infiltration with leachates from farms, organic waste dumps and sewage tanks (Adesiji et al., 2014).Zn has an average of $0.14 \mathrm{mg} \mathrm{L}^{-1}$ and ranges from $0.04 \mathrm{mg} \mathrm{L}^{-1}$ to $0.71 \mathrm{mg}$ $\mathrm{L}^{-1}$. Iron has an average of $0.07 \mathrm{mg} \mathrm{L}^{-1}$ and ranges from $0.01 \mathrm{mg} \mathrm{L}^{-1}$ to $0.143 \mathrm{mg} \mathrm{L}^{-1}$. The biological oxygen demand (BOD) of water samples within this study ranged between $0.1 \mathrm{mg} \mathrm{L}^{-1}$ to $17.9 \mathrm{mg} \mathrm{L}^{-1}$ with an average of $5.83 \mathrm{mg} \mathrm{L}^{-1}$. Table 2 classifies groundwater samples based on BOD. A high proportion (58\%) of groundwater samples within this study had BOD content greater than $3 \mathrm{mg} \mathrm{L}^{-1}$ indicating the presence of organic pollution, possibly infiltration of partially treated sewage from the improperly constructed septic tanks close to the wells(BIS, 2012)

Table 2: Classification of groundwater samples on the basis of biological oxygen demand

\begin{tabular}{lll}
\hline Classification & $\begin{array}{l}\text { BOD } \\
\left(\mathbf{m g ~ L}^{-1}\right)\end{array}$ & $\begin{array}{l}\text { Percentage in } \\
\text { present study }\end{array}$ \\
\hline Clean water & $1-2$ & $40 \%$ \\
Doubtful quality water & $3-5$ & $10 \%$ \\
Poor quality water & $>5$ & $30 \%$ \\
\hline
\end{tabular}

Potable water should contain not microorganism and the presence of $E$. Coli in water is highly indicative of sewage contamination (Olatunde et al., 2021). Total coliforms in water samples ranged from ND to $209 \times 10$ cfu $\mathrm{mL}^{-1}$ while $E$. Coli counts were in the range of ND to $45 \times 10 \mathrm{cfu} \mathrm{mL}^{-1} .67 \%$ of groundwater samples within this study contained bacterial coliforms while $45 \%$ of the groundwater sampled within this study contained E. Coli coliforms. The result of hydrogeochemical analysis of groundwater samples from Odeda local government was plotted on a piper trilinear diagram for visual identification of the hydrochemical facies present within the study area. The cations plot of the piper trilinear plot shows that about approximately $84 \%$ of the water samples fall within $\mathrm{Ca}^{2+}$ water type, about $7 \%$ of the water samples fall within the $\mathrm{Mg}^{2+}$ water type while approximately $10 \%$ do not present a dominant cation type (Figure2). Almost (74\%) all water samples fall within the chloride section of the anions plot. This shows that the dominant water type in the study area is the $\mathrm{Ca}^{2+}$ $\mathrm{Cl}^{-}$type.

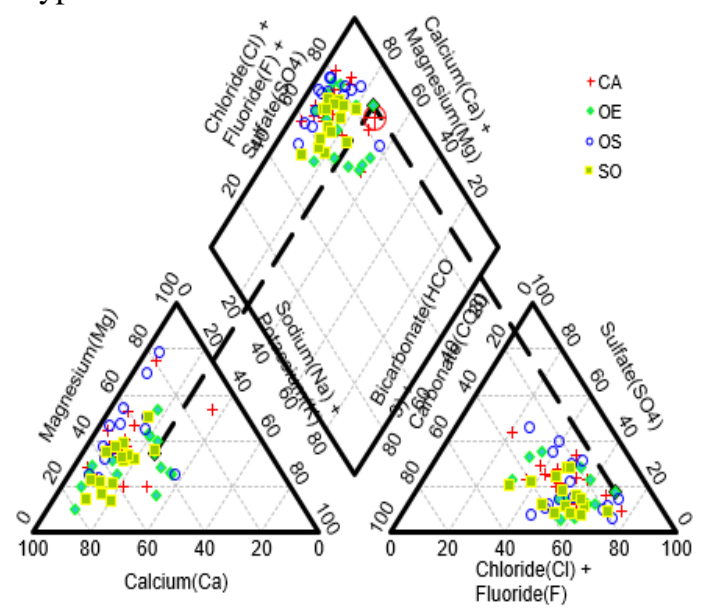

Fig 2: Piper trilinear diagram of the hydrogeochemical parameters of groundwater in the study area

A correlation analysis conducted to investigate the relationships between water quality parameters reveals that $\mathrm{Ca}^{2+}, \mathrm{Mg}^{2+}, \mathrm{Na}^{+}, \mathrm{K}^{+}$and $\mathrm{Cl}^{-}$main contributors to electrical conductivity, and are also significantly $(\mathrm{p}<$ $0.01)$ correlated with TDS. Similarly, the ion pairs $\mathrm{Ca}^{2+} / \mathrm{Mg}^{2+}, \mathrm{Na}^{+} / \mathrm{Ca}^{2+}, \mathrm{Na}^{+} / \mathrm{Cl}^{-}$and $\mathrm{Na}^{+} / \mathrm{K}^{+}$are also strongly correlated indicating that ions in each group could have originated from the same source. Nitrates and chlorides were also observed to be strongly correlated with BOD. Likewise, strong positive correlations were found between groundwater nitrate concentrations and total coliform counts.A principal component analysis resulted in a reduction of the initial dimension of the dataset, with the first four components explaining $68.79 \%$ of the total sample variance. The first Principal component $\left(\mathrm{PC}_{1}\right)$ accounts for $37.64 \%$ of the total variance and has strong loadings for $\mathrm{Ca}^{2+}, \mathrm{Mg}^{2+}$, EC and TDS (Table 3). $\mathrm{PC}_{1}$ is most likely associated with dissolutions from basal rocks such as shale and limestone. The second principal component $\left(\mathrm{PC}_{2}\right)$ which accounts for $16.96 \%$ of the total variance has strong loadings for $\mathrm{Na}^{+}, \mathrm{K}^{+}$, $\mathrm{NO}_{3}{ }^{-}$, and $\mathrm{Fe}$. Sodium, potassium and iron are associated with organic wastes and can be contributions from improper domestic waste disposals into groundwater. The third principal component $\mathrm{PC}_{3}$ accounts for $7.34 \%$ of the total variance and has strong loadings for $\mathrm{Cl}^{-}, \mathrm{NO}_{3}{ }^{-}$and $\mathrm{PO}_{4}{ }^{3-}$. These ions are indicators of sewage contamination (Ojekunle et al., 2020), most likely seepages or leachates from improperly built constructed septic tanks close by. $\mathrm{PC}_{4}$ 
accounts for $6.84 \%$ of the total variance and has strong loadings for $\mathrm{NO}_{3}^{-}, \mathrm{BOD}$ and $\mathrm{Zn}$. A high BOD in water samples indicates microbial activity and is most commonly used as an indicator of pollution from sewage. The relationships between groundwater quality parameters shown by $\mathrm{PCA}$ indicate $\mathrm{PC}_{1}$ is consistent with natural composition of water via dissolutions from basal rocks while $\mathrm{PC}_{2}, \mathrm{PC} 3$ and PC4 are consistent with contamination from unsanitary anthropogenic sources such as inappropriate sewage or greywater disposal.

Table 3 Rotated component matrix of PCA of groundwater quality parameters. Moderate to strong loadings are in bold.

\begin{tabular}{lllll}
\hline & $\mathbf{P C}_{1}$ & $\mathbf{P C}_{2}$ & $\mathbf{P C}_{\mathbf{3}}$ & $\mathbf{P C}_{4}$ \\
\hline $\mathrm{EC}$ & $\mathbf{0 . 8 7 6}$ & & 0.369 & \\
$\mathrm{TDS}$ & $\mathbf{0 . 8 6 6}$ & & 0.382 & \\
$\mathrm{Ca}$ & $\mathbf{0 . 7 4 5}$ & & & \\
$\mathrm{Mg}$ & & $\mathbf{0 . 7 4 1}$ & & \\
$\mathrm{Na}$ & & $\mathbf{0 . 7 1 5}$ & & \\
$\mathrm{K}$ & & $\mathbf{0 . 7 9 0}$ & & \\
$\mathrm{Cl}^{-}$ & 0.321 & & $\mathbf{0 . 6 2 0}$ & \\
$\mathrm{NO}_{3}{ }^{-}$ & & $\mathbf{0 . 8 0 5}$ & 0.432 & \\
$\mathrm{PO}_{4}{ }^{2-}$ & & & 0.473 & $\mathbf{0 . 6 1 2}$ \\
$\mathrm{SO}_{4}{ }^{2-}$ & & & & \\
$\mathrm{CO}_{3}{ }^{2-}$ & & & & \\
$\mathrm{Fe}_{\mathrm{Zn}}$ & & $\mathbf{0 . 5 2 0}$ & & \\
$\mathrm{BOD}$ & & & & $\mathbf{0 . 7 0 9}$ \\
$\mathrm{Tot}$ Coli & & & $\mathbf{0 . 7 3 0}$ & 0.479 \\
E. Coli & & & 0.493 & 0.439 \\
Eigen values & $\mathbf{4 . 1 7}$ & $\mathbf{2 . 2 3}$ & $\mathbf{1 . 5 1}$ & $\mathbf{1 . 3 7}$ \\
\% of variance & $\mathbf{3 7 . 6 4}$ & $\mathbf{1 6 . 9 6}$ & $\mathbf{7 . 3 4}$ & $\mathbf{6 . 8 4}$ \\
Cumulative \% & $\mathbf{3 7 . 6 4}$ & $\mathbf{5 4 . 6 0}$ & $\mathbf{6 1 . 9 4}$ & $\mathbf{6 8 . 7 9}$ \\
\hline
\end{tabular}

Conclusion: Monitoring for groundwater quality within Odeda local government area in Ogun State is a necessary part of ensuring environmental quality and safety. Results of water analysis showed that majority of the water quality parameters fell under study fell within regulatory limits. However, some water samples are observed to have high levels of BOD and microbial contamination. This is an indication of organic pollution most likely seepages from improperly constructed septic tank units close to the water sources.

\section{REFERENCES}

Adesiji, AR; Adeoye, PA; Gbadebo, AO (2014). Investigating the Effects of Sewage on the Groundwater Quality In Minna, Niger State, Nigeria. Ethiop. J. Environ. St. Manage.7 (1), 82 $-89$

BIS. Bureau of Indian Standard (2012). Indian standard drinking water - Specification (Second Revision)
Elemile, OO; Raphael, DO; Omole; DO; Oloruntoba, EO; Ajayi, EO; Ohwavborua, NA (2019). Assessment of the impact of abattoir effluent on the quality of groundwater in a residential area of Omu-Aran, Nigeria. Environ Sci. Eur, 31:16

Narany, TS; Ramli, MF; Aris, AZ; Sulaiman, WN; Fakharian, K (2014). Groundwater irrigation quality mapping using geostatistical techniques in Amol-Babol Plain, Iran. Arab. J. Geosci., 1-16

NSDWQ (2015). Nigerian Standard for Drinking Water Quality.Standards organization of Nigeria.Wuse, Abuja.

Ojekunle, OZ; Mujeeb, BA; Adeyemi, AA; Kayode AA; Abdulraheem, OA; Taiwo, AM; Ganiyu, SA (2020). Effects of industrialization on groundwater quality in Shagamu and Ota industrial areas of Ogun state, Nigeria. Heliyon, 6, e04353

Olatunde KA; Sarumi, M; Abdusalaam, S; Bada, B; Oyebanji, F (2021). Effect of modified septic tank on groundwater quality around Federal University of Agriculture, Abeokuta, south-west Nigeria. App. Environ. Res. 43(1):73-89

USAID (2018). New U.S.-supported 'e-wash' activity will bring clean water to three million Nigerians. [Online] Available from https://www.Usaid.Gov/Nigeria/Press-Releases [Assessed 13 January 2020].

WHO (2017). Guidelines for drinking water quality, fourth edition incorporating first addendum Edn.V.1Recommendation. Geneva. Pp. 515. 